\title{
Melt inclusions in rhyolite tuff of the Spor Mountain Formation, Utah track Be, U, Li through the magmatic-hydrothermal transition
}

\author{
Celestine N. Mercer ${ }^{1 *} \&$ Albert H. Hofstra ${ }^{1}$ \\ ${ }^{1}$ U.S. Geological Survey, Denver, CO (*cmercer@usgs.gov)
}

The fluorine- and lithophile-rich topaz rhyolites of the Miocene Spor Mountain Formation in western Utah host the Earth's largest Be deposit and a small U deposit. Beryllium is essential for aerospace, defense, computer, medical, and telecom applications, and has been catagorized as a strategic and critical element by the U.S. Department of the Interior [1] and the European Union [2]. In 2015, Spor Mountain produced $\sim 90 \%$ of the world's beryllium with a $\sim 70$-year supply remaining [3]. It is enriched in $\mathrm{Li}$, a potential byproduct [4]. Thus, it is an important location to investigate the process of $\mathrm{Be}, \mathrm{U}$, and $\mathrm{Li}$ enrichment $[4,5,6]$.

We combine new melt inclusion geochemistry (EMP, LA-ICP-MS), estimates of intensive parameters ( $\mathrm{P}, \mathrm{T}, \mathrm{a}_{\mathrm{TiO} 2}$ ), experimental phase equilibria [7], and experimentalthermodynamic fluid-melt partitioning models $[8,9]$ to track $\mathrm{Be}, \mathrm{U}$, and Li through the magmatic-hydrothermal transition to establish how these elements partitioned during magma ascent and degassing.

Concentrations of $\mathrm{Be}(\sim 10-100 \mathrm{ppm})$ and $\mathrm{F}(\sim 0.05-1.70$ $\mathrm{wt} \%)$ in melt inclusions show coherent incompatible variations, whereas $\mathrm{Li}(\sim 2500-5100 \mathrm{ppm})$ and $\mathrm{U}(\sim 15-48$ $\mathrm{ppm})$ are buffered by biotite, euxenite, and thorite $[6,7]$. Entrapment $\mathrm{P}$ and $\mathrm{T}$ define magma ascent ( $560-3 \mathrm{MPa})$ with melts cooling $\sim 55^{\circ} \mathrm{C} / 100 \mathrm{MPa}$. Experimental phase equilibria suggest saturation with a $\mathrm{CO}_{2}$-bearing aqueous fluid that likely caused lithophile elements to remain in the silicate melt [8]. Melt $\mathrm{F} / \mathrm{Cl}$ ratios increase exponentially with magma ascent indicating that degassing induced crystallization accelerated at $<200 \mathrm{MPa}$, at which point $\mathrm{CO}_{2}$ degassed rapidly and large amounts of $\mathrm{Cl}$ partitioned into the aqueous fluid [9]. These conditions theoretically favor an increase in lithophile $\mathrm{D}^{\text {fluid/melt }}[8]$, however, Be, U, and $\mathrm{Li}$ remained in the silicate melt as shallow as $\sim 8 \mathrm{MPa}$. We favor a process by which $\mathrm{Be}, \mathrm{U}$, and $\mathrm{Li}$ enrichment occurred entirely post-eruption, i.e., from leaching of rhyolite tuff and lavas by meteoric fluids rather than from shallowly exsolved magmatic fluids.

[1] Fortier (2018) USGS OFR 20181021. [2] Euro Com (2017) COM 490. [3] Lederer (2016) USGS FS 20163081. [4] Foley (2012) USGS SIR 20105070f. [5] Foley (2017) USGS PP 1802E. [6] Dailey (2018)

Am Min 103(8). [7] Webster (1987) Geo Cosmo Ac 51(3). [8]

Webster (1989) Econ Geol 84(1). [9] Burgisser (2015) Comp Geo 79. 